\title{
STUDI PENINGKATAN KARAKTERISTIK TANAH LEMPUNG DENGAN SERAT TANDAN KOSONG KELAPA SAWIT
}

\author{
Misnawati ${ }^{1}$ \\ ${ }^{1}$ Akademi Teknik Pembangunan Nasional Banjarbaru
}

\begin{abstract}
ABSTRAK
Stabilisasi tanah dimaksudkan untuk memperbaiki sifat-sifat tanah asli dengan cara antara lain menambahkan suatu bahan tertentu yang mengakibatkan perubahan sifat-sifat tanah asli. Selama ini penggunanaan serat tandan kosong banyak dihasilkan oleh industri perkebunan kelapa sawit. Serat merupakan jumlah terbesar ketiga setelah CPO dan tandan kosong kelapa sawit, tandan buah segar diperkirakan mengandung 14 - 15\%. Serat dapat dimanfaatkan sebagai bahan bakar alternatif energi pembangkit listrik, pembuatan kertas dan sebagai bahan campuran makanan ternak. Tapi sekarang serat juga digunakan untuk material konstruksi.

Penelitian ini dilakukan untuk menyelidiki prosentase optimum serat untuk mendapatkan kepadatan maksimum, menganalisis peningkatan nilai CBR tanah setelah penambahan serat, menganalisis peningkatan nilai qu pada pengujian UCT tanah setelah penambahan serat, menganalisis peningkatan nilai su pada pengujian vane shear test tanah setelah penambahan serat.

Penelitian dilakukan dengan mencampurkan serat tandan kosong kelapa sawit dengan tanah lempung lunak dengan kadar serat masing-masing 5\%, 6\%, 7\%, dan 8\%. Hasil pencampuran diharapkan dapat diketahui nilai bagaimana hubungan dari berbagai variasi prosen penambahan serat tandan kosong kelapa sawit guna mendapatkan tujuan yang diharapkan, selain itu hasil yang diperoleh diharapkan dapat memperbaiki kualitas tanah menjadi lebih baik. Berdasarkan hasil analisis dari penelitian ini, bahwa adanya penambahan serat tandan kosong kelapa sawit di dalam tanah lunak maka dapat memperbaiki kekuatan tanah tersebut sehingga menjadi meningkat dan hasil penelitian ini dapat digunakan sebagai acuan untuk stabilisasi tanah lempung.
\end{abstract}

Kata kunci: stabilisasi tanah, tanah lempung, serat tandan kosong kelapa sawit.

\section{PENDAHULUAN}

Dalam pengertian teknik secara umum tanah merupakan material yang terdiri dari agregat (butiran) mineral padat yang tidak tersementasi (terikat secara kimia) satu sama lain dan terdiri dari bahan-bahan organik yang telah melapuk (yang berpartikel padat) disertai dengan zat cair dan gas yang mengisi ruangruang kosong di antara partikel-partikel padat tersebut. Tanah terdiri dari butiran-butiran tanah itu sendiri serta ruang pori yang berisi air dan udara. Berdasarkan ukuran butiran, tanah diklasifikasikan menjadi empat kelas yaitu kerikil (gravel), pasir (sand), lanau (silt), dan lempung (clay). Lempung merupakan partikel yang berukuran kurang dari 0,002

Correspondence: Misnawati

Email: Misna.260789@gmail.com mm. Jika ditinjau dari segi mineral (bukan ukurannya), yang disebut dengan tanah lempung atau mineral lempung adalah tanah yang tersusun dari partikel-partikel mineral tertentu yang menghasilkan sifat-sifat plastis (Das, 1998).

Perbaikan tanah dengan stabilisasi merupakan salah satu pilihan untuk mengatasi kondisi tersebut. Stabilisasi tanah dimaksudkan untuk memperbaiki sifat-sifat tanah asli dengan cara antara lain menambahkan suatu bahan tertentu yang mengakibatkan perubahan sifat-sifat tanah asli tersebut. Disamping itu, stabilisasi tanah diperlukan dalam rangka memperbaiki sifatsifat tanah yang mempunyai daya dukung rendah, indeks plastisitas tinggi, pengembangan (swelling) tinggi dan gradasi yang buruk menjadi lebih baik untuk dasar suatu bangunan. 
Stabilisasi tanah atau perbaikan tanah yang dikenal dalam rekayasa geoteknik secara umum terbagi dalam tiga kategori yaitu; cara mekanis, cara kimia, dan cara fisik. Cara mekanis didasarkan atas usaha-usaha mekanis, seperti kompaksi dan konsolidasi. Melalui cara yang paling umum digunakan kerapatan tanah akan meningkat, kompresibilitas tanah berkurang, yang kemudian diikuti pula dengan peningkatan kapasitas daya dukung dan stabilitas tanah. Pada cara kimiawi, suatu bahan aditif berupa binders (semen, kapur) dicampurkan dalam tanah yang kemudian akan mengubah properties dan kekuatan tanah. Sedangkan pada cara fisik, suatu bahan perkuatan seperti geotekstil dimasukkan atau disusun pada lapisan tanah untuk memperkuat tanah.

Selama ini penggunanaan serat tandan kosong banyak dihasilkan oleh industri perkebunan kelapa sawit. Dengan salah satu sumber serat alam yang ketersediaannya melimpah di Indonesia dan digunakan langsung sebagai mulsa di perkebunan kelapa sawit atau dibakar dalam incinerator dan abunya dimanfaatkan sebagai substitusi pupuk kalium. Pemanfaatan tandan kosong lebih banyak dilakukan sebagai mulsa dengan menebarkan langsung ke areal perkebunan. Dimana mulsa tersebut dapat meningkatkan produksi tanaman dengan melepaskan unsur hara secara lambat ke tanah melalui mikroorganisme sehingga efektif dalam mendaur ulang unsur hara. Limbah padat serat tandan kosong sawit yang bersifat ekonomis sebagai alternatif lain bahan pencampur guna menstabilkan tanah lempung yang diharapkan mampu meningkatkan mutu tanah.

\section{METODE PENELITIAN}

\subsection{Penentuan Lokasi dan Bahan Sampling}

Lokasi untuk pengambilan sampel tanah dilakukan di Desa Pindahan Baru Kecamatan Rantau Badauh Kabupaten Barito Kuala, dengan jumlah titik pengambilan tanah tak terganggu (undisturbed) adalah dua titik pada kedalaman $\pm 2 \mathrm{~m}$ dan $\pm 3 \mathrm{~m}$, serta jumlah titik pengambilan tanah terganggu (disturbed) adalah satu titik pada kedalaman $\pm 0,2 \mathrm{~m}$. Bahan yang digunakan dalam penelitian ini adalah berupa sampel tanah lempung dan serat tandan kosong sawit. Tanah lempung diambil di Desa Pindahan Baru Kecamatan Rantau Badauh Kabupaten Barito Kuala dan serat tandan kosong sawit dari limbah perkebunan kelapa sawit Pelaihari Kabupaten Tanah Laut. Alat yang dipakai dalam penelitian ini adalah alat uji parameter sifat fisis dan mekanis tanah. Alat tersebut tersedia di laboratorium Mekanika Tanah Program Studi Teknik Sipil Universitas Lambung Mangkurat Banjarbaru.

\subsection{Pembuatan Sampel Tanah}

Sampel yang digunakan dalam studi ini merupakan sampel undisturbed, dan sampel disturbed yang dibuat di laboratorium dengan cara mencampurkan tanah lempung dan serat tandan kosong sawit. Adapun urutan pembuatan sampel dapat diuraikan sebagai berikut:

1. Penyediaan tanah lempung asli dalam keadaan basah (kondisi lapangan).

2. Penyediaan serat tandan kosong sawit.

3. Serat tandan kosong sawit dipotong dengan variasi $25 \mathrm{~mm}$ untuk pengujian CBR dan vane shear, sedangkan $10 \mathrm{~mm}$ untuk pengujian UCT.

4. Pencampuran tanah lempung dengan serat tandan kosong sawit dengan variasi campuran yang digunakan adalah 5\%,6\%, 7\%, dan $8 \%$ dari satu kantong tanah lempung seberat $2 \mathrm{~kg}$. Pencampuran secara manual dengan memutar baskom seperti mesin molen.

5. Setelah tahap tersebut selesai, sampel-sampel tanah hasil campuran diperiksa untuk mengetahui perubahan sifat mekanis tanah dengan menggunakan: pemadatan, $\mathrm{CBR}$, vane shear dan UCT.

\subsection{Penentuan kadar serat optimum}

Uji pemadatan bertujuan untuk mendapatkan grafik hubungan antara berat volume $(\gamma)$ terhadap kadar serat. Adapun urutan pengujian pemadatan sebagai berikut:

1. Siapkan tanah lempung kondisi lapangan dalam keadaan basah sebanyak 2000 gram (A).

2. Siapkan serat tandan kosong kelapa sawit dalam kondisi kering udara yang sudah dipotong 
sepanjang masing-masing $25 \mathrm{~mm}$, kemudian ditimbang sebanyak $\mathrm{B}=5 \% \mathrm{~A}, \mathrm{C}=6 \% \mathrm{~A}, \mathrm{D}=$ $7 \% \mathrm{~A}$, dan $\mathrm{E}=8 \% \mathrm{~A}$.

3. Tanah yang sudah disiapkan (A) dicampur dengan 5\% serat (B) secara bersamaan, kemudian diaduk dalam baskom hingga tercampur merata.

4. Setelah dicampur $(A+B)$, tanah dimasukkan ke dalam mold dan diuji pemadatan, pengujian dilakukan dengan 25 pukulan sebanyak 3 layer.

5. Sampel benda uji ditimbang dan hitung kepadatan yang dihasilkan dari pemadatan tersebut, kemudian lakukan kembali pengujian untuk $6 \%$ serat (C), $7 \%$ serat (D) dan $8 \%$ serat (E).

\subsection{Pembuatan sampel uji CBR dan vane shear test}

Uji CBR bertujuan untuk mendapatkan perbandingan antara beban penetrasi suatu beban terhadap beban standar dengan kedalaman dan kecepatan penetrasi yang sama dengan penambahan serat. Sedangkan uji vane shear test bertujuan untuk mendapatkan nilai kuat geser tanah kondisi undrained. Adapun urutan pengujian CBR dan vane shear test sebagai berikut:

1. Siapkan tanah lempung kondisi lapangan dalam keadaan basah sebanyak 2000 gram (A).

2. Siapkan serat tandan kosong kelapa sawit dalam kondisi kering udara yang sudah dipotong sepanjang masing-masing $25 \mathrm{~mm}$, kemudian ditimbang sebanyak $\mathrm{B}=5 \% \mathrm{~A}, \mathrm{C}=6 \% \mathrm{~A}, \mathrm{D}=$ $7 \% \mathrm{~A}, \mathrm{E}=8 \% \mathrm{~A}$ dan $\mathrm{F}=6,22 \% \mathrm{~A}$.

3. Tanah yang sudah disiapkan (A) dicampur dengan 5\% serat (B) secara bersamaan, kemudian diaduk dalam baskom hingga tercampur merata.

4. Setelah dicampur $(A+B)$, tanah dimasukkan ke dalam mold dan ditumbuk dengan pukulan masing-masing 10, 25 dan 56 pukulan , serta dalam tiap mold dibagi sebanyak 3 layer.

5. Sampel benda uji ditimbang dan diuji dengan alat pengujian $\mathrm{CBR}$, kemudian pada sisi yang berlawanan dari arah pengujian CBR (sisi bawah) diuji kembali vane shear test.

6. Setelah itu lakukan kembali pengujian untuk $6 \%$ serat (C), $7 \%$ serat (D), $8 \%$ serat (E) dan $6,22 \%$ A.

\subsection{Pembuatan sampel uji UCT}

Uji UCT bertujuan untuk mendapatkan besarnya gaya aksial per satuan luas pada saat benda uji mengalami keruntuhan atau pada saat regangan aksial mencapai $20 \%$ dengan penambahan serat. Adapun urutan pengujian UCT sebagai berikut:

1. Siapkan tanah lempung kondisi lapangan dalam keadaan basah sebanyak 400 gram (A).

2. Siapkan serat tandan kosong kelapa sawit dalam kondisi kering udara yang sudah dipotong sepanjang masing-masing $10 \mathrm{~mm}$, kemudian ditimbang sebanyak $\mathrm{B}=5 \% \mathrm{~A}, \mathrm{C}=6 \% \mathrm{~A}, \mathrm{D}=$ $7 \% \mathrm{~A}$, dan $\mathrm{E}=8 \% \mathrm{~A}$.

3. Tanah yang sudah disiapkan (A) dicampur dengan 5\% serat (B) secara bersamaan, kemudian diaduk dalam baskom hingga tercampur merata.

4. Setelah dicampur $(A+B)$, tanah tersebut dimasukkan ke dalam ring UCT hingga sama dengan kepadatan masing-masing variasi pada uji pemadatan.

5. Sampel diuji pada alat pengujian UCT, kemudian lakukan kembali pengujian untuk $6 \%$ serat (C), 7\% serat (D) dan 8\% serat (E).

\section{HASIL DAN PEMBAHASAN}

Dari penelitian yang telah dilakukan, akan diuraikan data hasil penelitian mengenai sifat fisis dan mekanis tanah lempung. Sifat fisis tanah asli meliputi kadar air, berat volume, berat jenis, batas cair dan batas plastis tanah. Adapun sifat mekanis tanah adalah pemadatan, CBR, vane shear test dan UCT sebelum dan sesudah penambahan serat tandan kosong sawit.

Hasil pengujian menunjukkan adanya perubahan nilai-nilai CBR dan UCT yang terjadi akibat adanya penambahan serat tandan kosong kelapa sawit. Perubahan parameter tersebut terjadi seiring dengan adanya penambahan kadar serat tandan kosong kelapa sawit yang digunakan. Komposisi kadar serat yang digunakan sangat berpengaruh pada kekuatan tanah yang dihasilkan, misalnya nilai CBR tanah.

Pada kadar serat 5\% sampai dengan 6,22\% (kadar serat optimum) nilai CBR tanah semakin meningkat, kemudian setelah 


\section{STUDI PENINGKATAN KARAKTERISTIK TANAH LEMPUNG DENGAN SERAT \\ TANDAN KOSONG KELAPA SAWIT \\ Misnawati}

melebihi kadar serat optimum nilai CBR tanah akan terus menurun. Hal yang terjadi seperti itu dipengaruhi oleh fisik benda uji yang berubah secara signifikan setelah penambahan serat tandan kosong kelapa sawit. Pada kadarserat $5 \%, 6 \%$ dam $6,22 \%$ kondisi sampel benda uji terlihat semakin padat dengan adanya penambahan serat seperti terlihat pada Gambar 1, Gambar 2 dan Gambar 3. Sedangkan pada kadar serat $7 \%$ dan $8 \%$ kondisi benda uji sudah didominasi oleh serat, bahkan pada kadar serat $8 \%$ kondisi sampel benda uji sebagian berongga karena terlalu banyak serat yang digunakan, sehingga serat dan tanah sulit untuk bersatu dan volume serat yang digunakan terlalu besar, seperti terlihat dalam Gambar 4 dan Gambar 5. Secara kuantitatif volume mold yang digunakan untuk pengujian CBR adalah $749,82 \mathrm{~cm} 3$, berat volume serat adalah $0,04489 \mathrm{gr} / \mathrm{cm} 3$, berarti secara teoritis berat serat yang digunakan untuk memenuhi mold benda uji adalah sebanyak $(749,82 \mathrm{~cm} 3)(0,04489 \mathrm{gr} / \mathrm{cm} 3)=$ 33,66 gram, sedangkan pada kadar serat 7\%, jumlah kadar serat yang digunakan adalah 140 gram, berarti setara dengan $(140 \mathrm{gr}) /(33,66 \mathrm{gr})$ $=4,16$ volume mold benda uji, hal ini menunjukkan bahwa setelah kadar serat optimum, volume serat yang digunakan lebih mendominasi dari pada tanah yang digunakan.

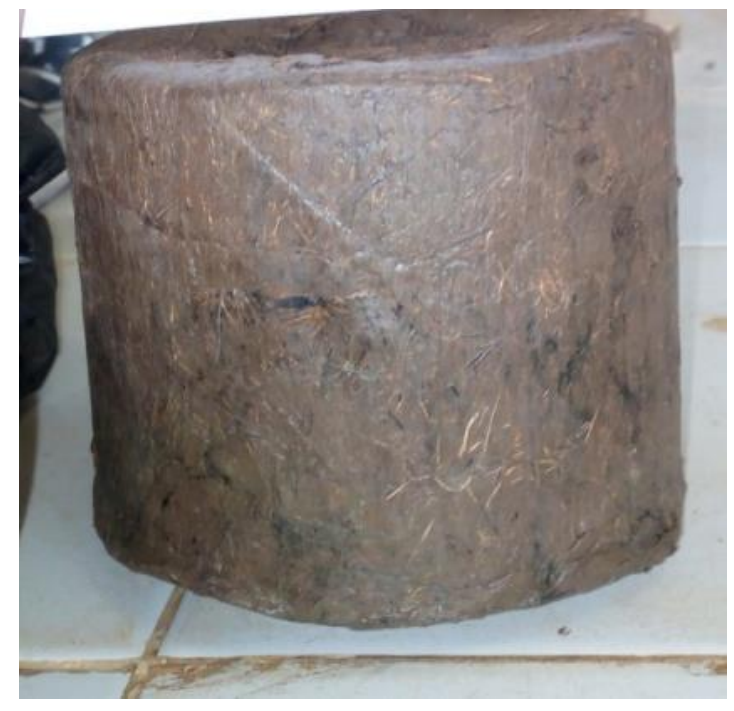

Gambar 1. Sampel Benda Uji CBR untuk Kadar Serat 5\%

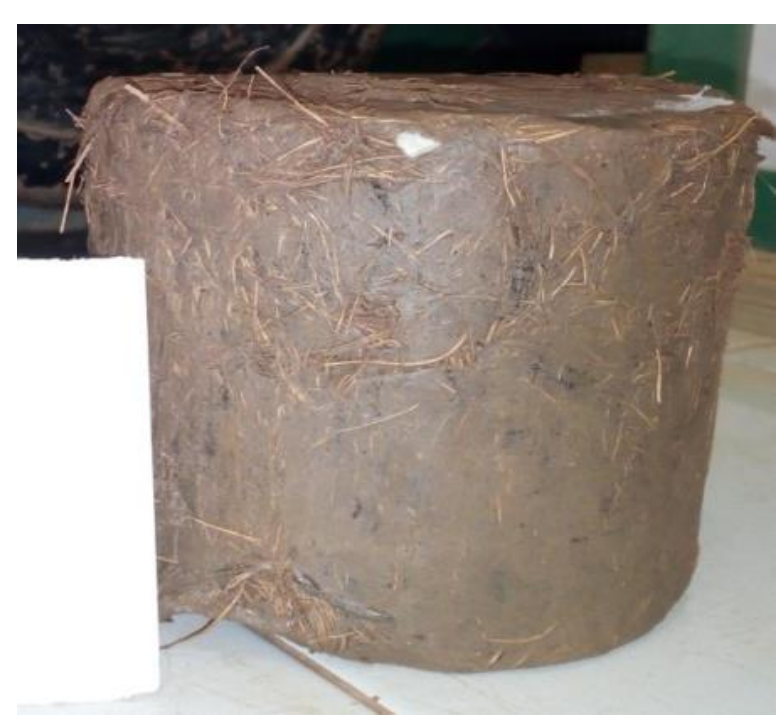

Gambar 2. Sampel Benda Uji CBR untuk Kadar Serat 6\% 


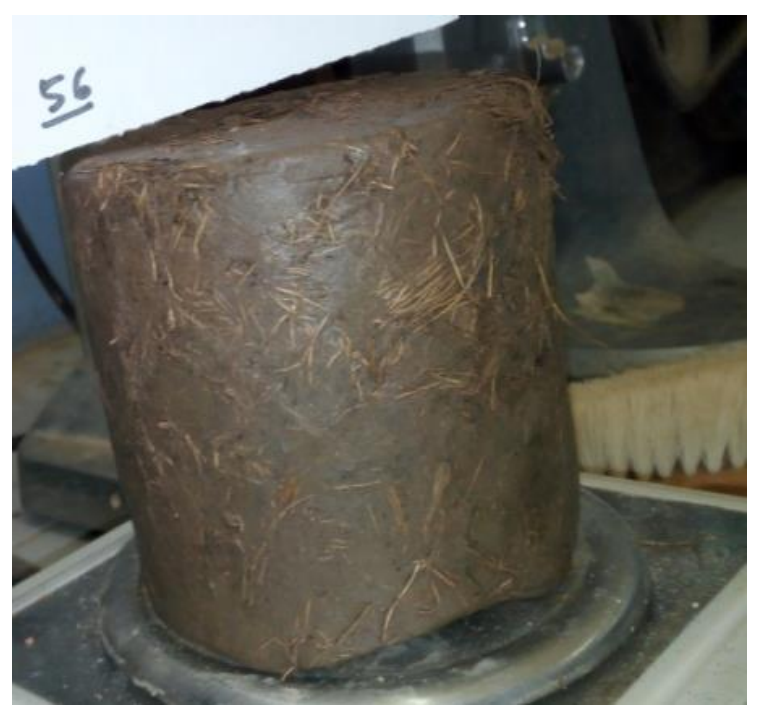

Gambar 3. Sampel Benda Uji CBR untuk Kadar Serat 6,22\%

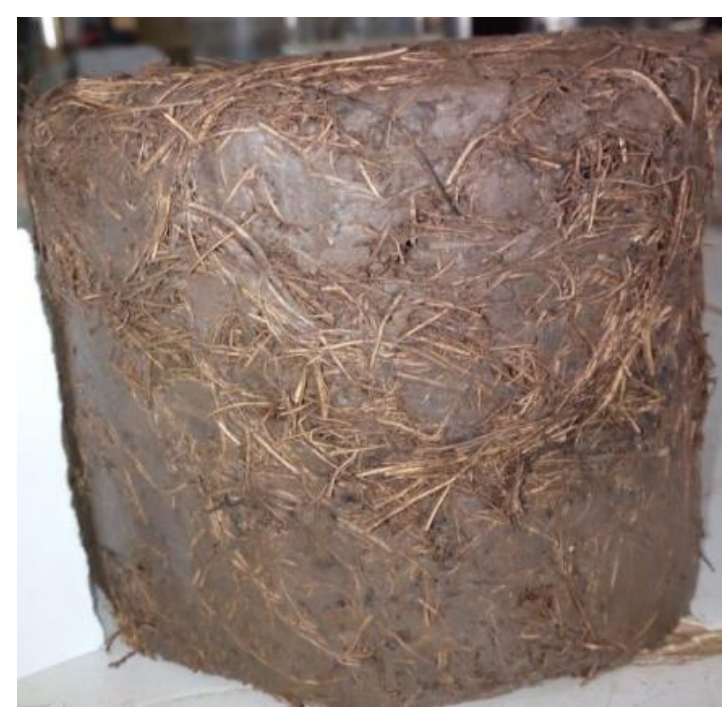

Gambar 4. Sampel Benda Uji CBR untuk Kadar Serat 7\%

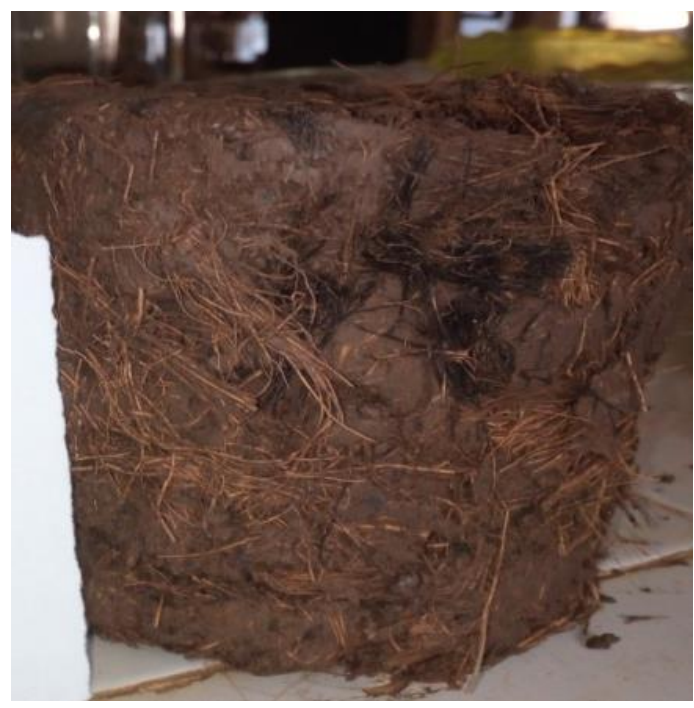

Gambar 5. Sampel Benda Uji CBR untuk Kadar Serat 8\% 


\section{KESIMPULAN}

Berdasarkan hasil analisis terhadap hasil penelitian yang dilakukan dapat disimpulkan beberapa hal sebagai berikut.

1. Adanya serat dapat meningkatkan kepadatan tanah yang semula tidak dapat dipadatkan menjadi dapat dipadatkan. Dari hasil penelitian ini didapatkan kadar serat optimum sebesar 6,22\% dengan kepadatan maksimum yang dihasilkan sebesar 1,398 gram $/ \mathrm{cm} 3$.

2. Nilai CBR terus meningkat dari awal penambahan serat hingga kadar serat yang ditambahkan mencapai kadar serat optimum. Kemudian setelah penambahan serat melebihi kadar serat optimum yang digunakan, maka nilai CBR tanah akan semakin menurun, nilai CBR maksimum yang dihasilkan sebesar 6\% pada kadar serat $6,22 \%$ (kadar serat optimum), sehingga tanah tersebut dapat digunakan sebagai subgrade disparation.

3. Nilai UCT tanah akan semakin meningkat dengan adanya penambahan serat sampai kadar serat yang ditambahkan sebesar 7\% dan nilai UCT akan mengalami penurunan setelah penambahan serat melebihi kadar serat $7 \%$, nilai UCT maksimum dihasilkan pada kadar serat $7 \%$ dengan nilai qu sebesar $0,7825 \mathrm{~kg} / \mathrm{cm} 2$.

4. Nilai tahanan geser tanah (su) pada pengujian vane shear test terus mengalami peningkatan dari awal penambahan serat hingga kadar serat yang ditambahkan mencapai kadar serat optimum (kadar serat $6,22 \%$ ). Kemudian setelah penambahan serat melebihi kadar serat optimum yang digunakan, maka nilai su tanah akan semakin menurun, nilai su maksimum yang dihasilkan sebesar 53,5 $\mathrm{kPa}$ pada kadar serat $6,22 \%$ (kadar serat optimum).

\section{DAFTAR RUJUKAN}

Arifin, Y.F. dan Markawie. 2013. Stabilisasi Tanah Lempung Lunak dengan Kapur pada Kondisi Kadar Air Lapangan. Info Teknik. Volume 14 No 1, Juli, 2013. Hal 26-34
Aswadi. 2017. Stabilisasi Tanah Lempung Sungai Tabuk dengan Campuran Serbuk Limbah Arang Kayu dan Semen. Skripsi Program Studi Teknik Sipil Fakultas Teknik. Universitas Lambung Mangkurat. Banjarbaru

Bowles, J.E. 1986. Sifat-Sifat Fisis dan Geoteknis Tanah. Edisi Kedua. Terjemahan oleh Johan K. Hainim. Penerbit Erlangga. Jakarta

Das, B.M. 1998. Mekanika Tanah Jilid 1 Prinsip-Prinsip Rekayasa Geoteknis. Terjemahan oleh Noor E. Mochtar. Penerbit Erlangga. Jakarta

Faisal, M. dan Robby, M. 2006. Pemanfaatan Limbah Gas Karbit sebagai Bahan Stabilisasi Tanah Lempung. Skripsi Program Studi Teknik Sipil Fakultas Teknik. Universitas Lambung Mangkurat. Banjarbaru

Firdaus, T. 2017. Pengaruh Penambahan Serbuk Limbah Arang Кауи Terhadap Sifat Fisis dan Mekanis Tanah Lempung. Skripsi Program Studi Teknik Sipil Fakultas Teknik. Universitas Lambung Mangkurat. Banjarbaru

Fitriansyah, M. 2016. Penerapan Zat Alkali untuk Meningkatkan Daya Dukung Tanah Lempung untuk Subgrade Jalan Raya. Tesis Program Pascasarjana Program Studi Teknik Sipil. Universitas Lambung Mangkurat. Banjarmasin

Hardiyatmo, H.C. 2002. Mekanika Tanah I. Edisi Ketiga. Gadjah Mada University Press. Yogyakarta

Ismail. 2011. Properties of Laterite Brick Reinforced with Oil Palm Empty Fruit Bunch Fibres. Pertanika J. Sci. Technol. Volume 19 No 1, April, 2011. Hal 33-43

Muntohar, A.S. 2005. Rekayasa Geoteknik. Laboratorium Mekanika Tanah Universitas Muhammadiyah Yogyakarta Press. Yogyakarta 
Supriadi. 2014. Pengaruh Perlakuan Alkali terhadap Kekuatan Tarik Serat Tandan Kosong Kelapa Sawit untuk Digunakan pada Komposit Serat TKKS. Jurnal Mechanical. Volume 5 No 1, Maret, 2014. Hal 38-44

Soedarmo, D. dan Purnomo, E. 1993. Mekanika Tanah 1. Penerbit Kanisius. Malang

Yulindasari., Dewi, R. dan Yudhistira, H. 2015. Pengaruh Penambahan Abu Tandan Sawit dan Gipsum Terhadap Tanah Lempung Lunak Berdasarkan Pengujian CBR. The 18th FSTPT International Symposium. Universitas Lampung. Bandar LampungDili - Timor Leste). Media Teknik Sipil Volume 13 Nomor 1 ISSN 1693-3095. 